\title{
Reproductive Biology of Glossogobius giuris (Hamilton), in Manchar Lake Sindh, Pakistan
}

\author{
Qambrani GR ${ }^{2}$, Soomro AN ${ }^{1}$, Palh ZA** Baloch WA1, Tabasum S³, Lashari KH ${ }^{1 *}$ and Qureshi MA \\ ${ }^{1}$ Department of Freshwater Biology and Fisheries, University of Sindh, Jamshoro, Pakistan \\ ${ }^{2}$ Fisheries Department, University of Sindh, Sindh, Pakistan \\ ${ }^{3}$ Institute of Plant Sciences, University of Sindh, Jamshoro, Pakistan \\ ${ }^{4}$ Centre for Environmental Sciences, University of Sindh, Jamshoro, Sindh, Pakistan
}

\begin{abstract}
The study was carried out to elaborate the reproductive aspects, including size at sexual maturity, reproductive season, reproductive potential, and egg size of Glossogobius giuris from Manchar lake, Sindh, Pakistan for the first time. Manchar lake is polluted lake, it is situated in district Jamshoro. The survey was conducted from February to December 2010. In total 335 specimens comprising of 159 females and 176 males were brought to the laboratory. Fish specimen were measured for total length $(\mathrm{cm})$ and weighed $(\mathrm{g})$ on digital balance. After dissection gonads of each specimen were weighed. Gonadosomatic Index was calculated as $G S I=(G W \times 100) / B W$; Ovaries were preserved for fecundity estimation. The total length of smallest and largest specimen observed was $9.5 \mathrm{~cm}-24.8 \mathrm{~cm}$, respectively. First size at the sexual maturity of female $G$. giuris was observed $9.5 \mathrm{~cm}$. Gonadosomatic Index of $G$. giuris was high from April to June. Fecundity of fish ranged between 7346.45 to 39750.45 . The average fecundity of G. giuris was $24835.84 \pm 10361.74$. Study revealed that fecundity of G. giuris in Manchar lake is not as high as in neighboring countries. Study also revealed that the species has single and short spawning season in Manchar lake.
\end{abstract}

Keywords: Glossogobius giuris; Reproductive biology; Manchar lake; Chotiari reservoir

\section{Introduction}

Gobies are originally marine species, which are still under the process of fresh waterization. Due to their marine origin still many freshwater gobies are observed to tolerate high salinity ranges.

Therefore large numbers of marine gobies are reported to inhabit in freshwaters.

Distribution range of Glossogobius giuris (Hamilton) is reported from freshwater and estuaries of Bangladesh, India, Pakistan, and Burma [1]. In Pakistan, the fish is reported in all types of freshwaters in warm areas [2]. This fish is also reported from Chotiari Reservoir [3]. Most of the published worked on biological aspects of G. giuris is from our neighboring countries [4-6]. Previously in Pakistan studies are available on growth and feeding habit of the species $[7,8]$.

Gonadosomatic Index (GSI) is most useful tool in fisheries biology to determine the spawning season of spawning. Knowledge about Gonadosomatic Index and fecundity of any fish is important for understanding its life history, and evaluating the potential of its stock for commercial purposes. Furthermore, such knowledge is also needed for the sound management for the conservation of the Gupta and Shrivastava [9-12].

\section{Materials and Methods}

Fish samples for the current study were collected from Manchar lake over the period of one year from January 2010 to December 2010. The fish samples were carried in ice box to the laboratory, where further observations were made. In the laboratory fishes were sexed, body measurements for total length (TL) were carried out at centimetre scale $(0.1 \mathrm{~cm})$ with the help of measurement tap and weighed $(\mathrm{g})$ using scale. Body weight were taken with the help of, later on fishes were gutted to check the gonadal statu/maturation.

Gonadosomatic index (GSI) was calculated with following formula

$$
\mathrm{GSI}=(\mathrm{Gw} \times 100) / \mathrm{Bw}
$$

Where Gw stands for gonadal weight and Bw for the body weight

Eggs size measurement made with the help of Trinocular Microscope (Nikon ECLIPSE E200).

Fecundity estimations were by gravimetric method

$\mathrm{F}=(\mathrm{Wss} \times \mathrm{N} / \mathrm{Gw})$ average of three sub.samples $)$

Wss = weight of subsamples

$\mathrm{N}=$ average number of eggs

$\mathrm{Gw}=$ Gonadal weight

Fecundity was estimated by taking three subsamples of equal weight from anterior, middle and posterior portions of the ovary. The counting of eggs was carried out Dissecting Microscope (KYOWA TOKYO).

Egg size was measured during each month, small piece of ovary was removed it was placed on slide, the sketches of eggs were made under Trinocular Microscope (Nikon ECLIPSE E200) and with the help of drawing tube.

*Corresponding authors: Khalid Hussain Lashari, Department of Freshwate Biology and Fisheries, University of Sindh, Jamshoro, Pakistan, Tel: 9222921318190; E-mail: kh1lashari@gmail.com

Zameer Ali Palh, Centre for Environmental Sciences, University of Sindh, Jamshoro, Sindh, Pakistan, Tel: 9222921318190; E-mail: zameer_ali110@hotmail.com

Received September 23, 2015; Accepted October 19, 2015; Published January 15,2016

Citation: Qambrani GR, Soomro AN, Palh ZA, Baloch WA, Tabasum S, et al. (2015) Reproductive Biology of Glossogobius giuris (Hamilton), in Manchar Lake Sindh, Pakistan. J Aquac Res Development 6: 392. doi:10.4172/2155-9546.1000392

Copyright: (c) 2015 Qambrani GR, et al. This is an open-access article distributed under the terms of the Creative Commons Attribution License, which permits unrestricted use, distribution, and reproduction in any medium, provided the original author and source are credited. 
Citation: Qambrani GR, Soomro AN, Palh ZA, Baloch WA, Tabasum S, et al. (2015) Reproductive Biology of Glossogobius giuris (Hamilton), in Manchar Lake Sindh, Pakistan. J Aquac Res Development 6: 392. doi:10.4172/2155-9546.1000392

Page 2 of 3

\section{Results}

A total 335 specimen comprising 159 females and 176 males were examined to determine the reproduction of G. giuris. Percentage of male and female population was $52.53 \%$ and $47.46 \%$ respectively. The smallest size of mature female was $9.4 \mathrm{~cm}$ (Table 1).

The fish exhibits clear sexual dimorphism, male were with straight, thin and pointed genital papilla while females were with short fleshy and circular genital papilla (Figure 1). Total length of smallest and largest female carrying the mature ovaries recorded $9.4 \mathrm{~cm}$ and 24.8 $\mathrm{cm}$, respectively. G. giuris mature females were found with a pair of granular ovaries unequal in length and fully ripen ovaries were orange in color. Based on the smallest size of female with the mature ovaries it can be said that first size of G. giuris at the sexual maturity was $9.4 \mathrm{~cm}$.

Increase in Gonadosomatic Index was observed from February; however it peaked in the month of March and it also remained high from April and June, then after it declined from July to September (Figure 2). It shows that the fish has prolonged breeding period which persists from March to September in Manchar Lake.

\begin{tabular}{|l|l|c|c|c|c|c|}
\hline Sex & No & Percentage & $\begin{array}{c}\text { Minimum } \\
\text { length }\end{array}$ & $\begin{array}{c}\text { Maximum } \\
\text { length }\end{array}$ & Mean \pm STD & $\begin{array}{c}\text { Confidence } \\
\text { level }\end{array}$ \\
\hline Male & 176 & 52.53 & $9(\mathrm{~cm})$ & $21.5(\mathrm{~cm})$ & $15.34 \pm 2.72$ & 0.38 \\
\hline Female & 159 & 47.46 & $9.4(\mathrm{~cm})$ & $24.8(\mathrm{~cm})$ & $15.44 \pm 2.47$ & 0.4 \\
\hline
\end{tabular}

Table 1: Descriptive statistics on total length $(\mathrm{cm})$ of Glossogobius giuris in Manchar lake, Sindh, Pakistan.

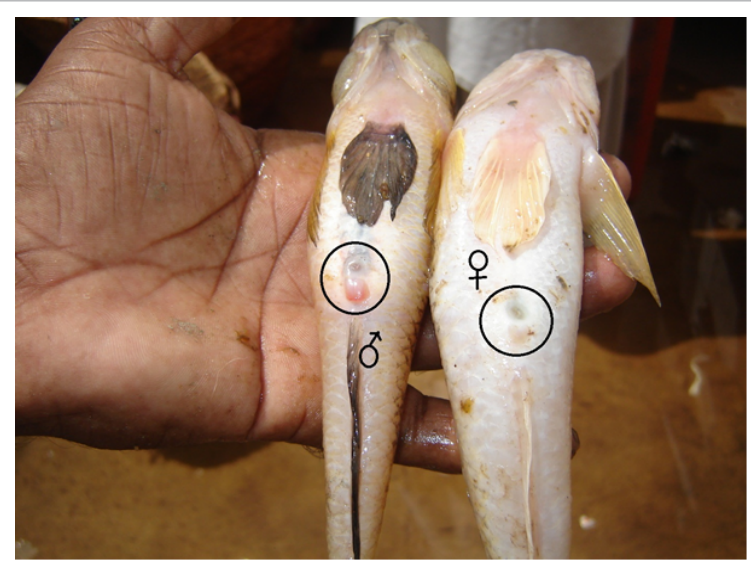

Figure 1: Both sexes of Glossogobiusgiuris showing distinct sexual dimorphism, males exhibiting prominent papilla.

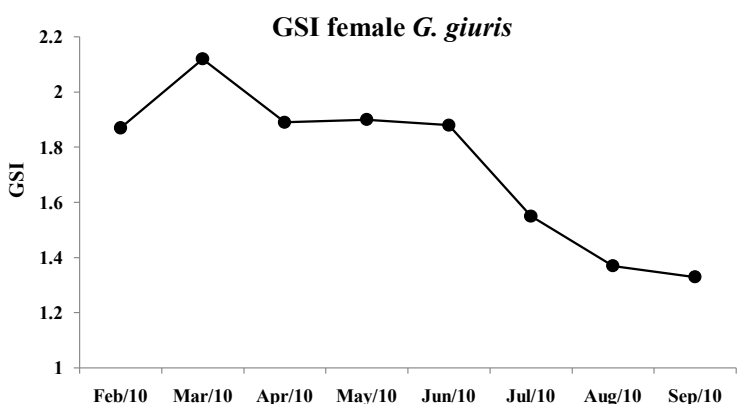

Figure 2: Monthly change in Gonadosomatic Index of G. giuris.

\begin{tabular}{|l|c|c|c|}
\hline $\begin{array}{l}\text { Total length }(\mathbf{c m}) \\
\text { mean } \pm \text { STDEV }\end{array}$ & $\begin{array}{c}\text { Total weight }(\mathbf{g}) \\
\text { mean } \pm \text { STDEV }\end{array}$ & $\begin{array}{c}\text { Gonadal weight } \\
(\mathbf{g}) \text { mean } \pm \text { SD }\end{array}$ & $\begin{array}{c}\text { Fecundity mean } \\
\pm \text { SD }\end{array}$ \\
\hline $17.32 \pm 5.01$ & $31.90 \pm 10.11$ & $1.77 \pm 0.67$ & $24835 \pm 10361.74$ \\
\hline
\end{tabular}

$\mathrm{SD}=$ Slandered deviation

Table 2: Mean and slandered deviation of different body parameters and fecundity of Glossogobius giuris in Manchar lake.
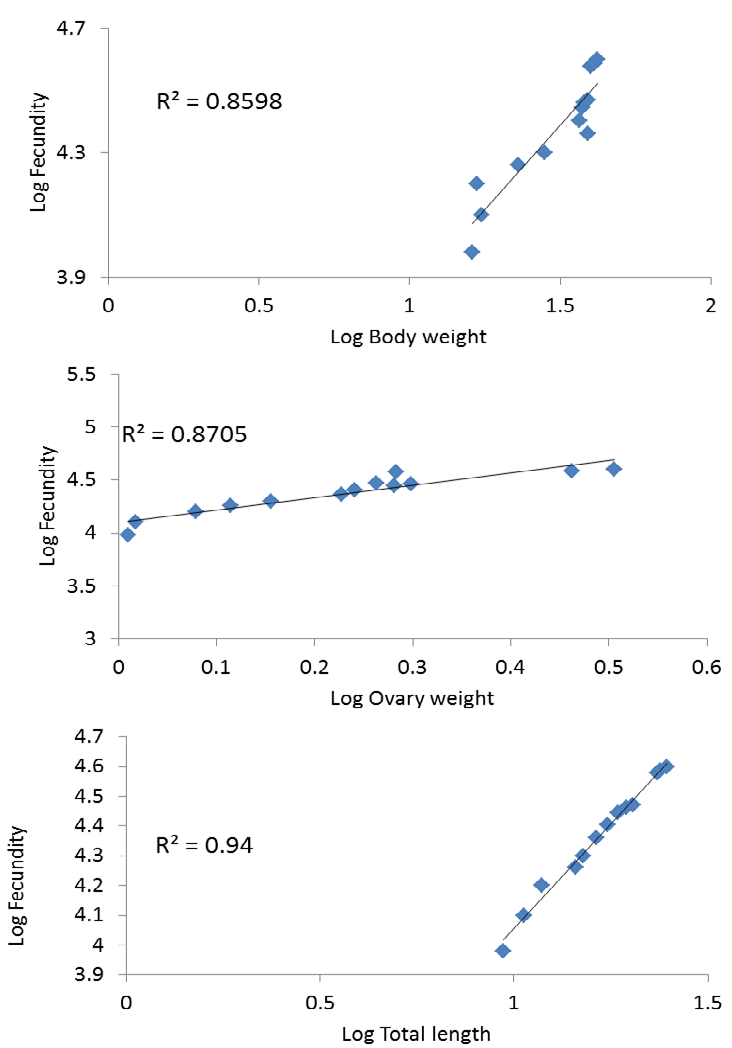

Figure 3: Regression analysis between log values of fecundity with different body parameters (body weight; ovary weight and total length).

For fecundity analysis total 13 females were used, their total length ranged between $9.4 \mathrm{~cm}$ to $24.8 \mathrm{~cm}$. Fecundity of G. giuris ranged from 7346.45 to 39750.45 . The average fecundity of G. giuris was $24835.84 \pm$ 10361.74 (Table 2).

Regression analysis between log values of total length and fecundity, gonadal weight and fecundity and total weight and fecundity showed significant relationship. However, fecundity showed comparatively high correlation with total length and gonadal weight, respectively (Figure 3).

The eggs of G giuris were very small and oval is shape, size ranged between 0.17 to $0.75(\mathrm{~mm})$ on their longitudinal axis, The average value of egg size was $0.36 \pm 0.13 \mathrm{~mm}$ (Table 3 ).

\section{Discussion}

Glossogobius giuris exhibited distinct sexual dimorphism, male were found with thin and pointed genital papilla. External sexual dimorphism helps to study the reproductive biology of fishes, and life history traits it also support for determining morphological difference between populations [13]. In total 335 specimens were used to determine the reproduction of G. giuris. The study is based on large number of specimen, percentage of male and female population 
Citation: Qambrani GR, Soomro AN, Palh ZA, Baloch WA, Tabasum S, et al. (2015) Reproductive Biology of Glossogobius giuris (Hamilton), in Manchar Lake Sindh, Pakistan. J Aquac Res Development 6: 392. doi:10.4172/2155-9546.1000392

\begin{tabular}{|c|c|c|}
\hline Minimum & Maximum & Mean \pm SD. \\
\hline 0.17 & 0.75 & $0.36 \pm 0.13$
\end{tabular}

Table 3: Mean and standard deviation of egg size of G. giuris.

(52.53\% and $47.46 \%$, respectively) indicating the dominance of female population which is considered as most observed phenomena is fishes and reported for many species by different authors [14].

Based on the size of smallest female carrying the mature ovaries ( 9.4 $\mathrm{cm})$, this can be concluded that the maturity size of the fish in Manchar lake is $9.4 \mathrm{~cm}$. Previously size of sexual maturity was estimated based on smallest egg bearing female by Soomro et al. [10].

Gonadosomatic index of G. giuris was higher from February to September it declined then after, suggesting that the species has single breeding season which last from April to July, previously single and prolonged breeding season for G. giuris was observed from Bangladesh in Payara river Bangladesh [12]. However in other study from Bangladesh same fish was reported to breed several times in a year [15].

Fecundity of G. giuris in the present study ranged between 7346.45 to 39750.45 , previously similar fecundity for G. giuris was observed by Doha, (10760-29580), Although previously from the Payali River Bangladesh fecundity of same species was observed much high (88495 to 264104). Variations in fecundity of a same species in different environment are not exceptional case [12]. Such variations can be attributed to food availability, fish stock, maturity stages and other environmental factors $[9,12]$. Small sized fishes are reported to have matured earlier in smaller size class and they bear small sized eggs, low fecundity [16].

All the body parameters (total length, gonadal weight and body weight) showed better relationship with fecundity in the result of regression analysis, similar findings are reported by Roy et al. and Khan et al. [12,17]. Increase in fecundity with increase in total length is related with the growth in body, linear relationship between total length and fecundity is also much evident phenomena in fishes. Soomro Study revealed that G. giiuris has single spawning season in Manchar lake, Sindh, with peak from April to June [10].

\section{Conclusion}

The study gives the first information regarding any reproductive aspect of the species from Pakistan. This basic information will be helpful for the fisheries management and conservation of the species.

\section{References}

1. Bhuiyan AL (1964) Fishes of Dhacca Assiatic So Pak Dacca.

2. Mirza MR, Bhatti MN (1999) Biodiversity of the freshwater fishes of Pakistan and Azad Kashmir. In: Proc. Sem. Aquatic Biodiversity of Pakistan (eds) QB Kazmi and MA Kazmi).
3. Leghari MK, Sahito GA, Arbani SN, Leghari MY(1997) Ecological survey of phytoplankton in Fresh water take, Baker (Distt, Sanghar), Sindh, Pakistan, Sindh Univ Res J Sci Sr 29: 83-94.

4. Islam MN (2004) Eco-biology of freshwater gobi, Glossogobius guiris (Hamilton) of the river of Padma in relation to its fishery. Journal of Biological Sciences 6 : 780-793.

5. Islam MN, Joadder MAR (2005) Seasonal variation of the proximate composition of freshwater gobi, G. giuris (Hamilton) from the river Padma. Pakistan Journal of Biological Sciences 8: 532-536.

6. Joadder AR (2009) Length Weight relationship and condition factor $(K n)$ of Glossogobius giuris (Hamilton) from Atrai River in northern part of Bangladesh. J Fisheries International 4: 1-4.

7. Achakzai WM, Achakzai SWM, Baloch WA Qambrani GR, Soomro AN (2014) Length-Weight Relationship and Condition Factor of Baloch,Tank Goby Glossogobius giuris (Hamilton and Buchnnan, 1822) from Manchar lake District Jamshoro, Sindh, Pakistan. Sindh. Univ Res J Sci Ser 46: 213-216.

8. Achakzai WM, Saddozai S, Baloch WA, Masood Z, Rehman HU, et al. (2015) Food and Feeding Habits of Glossogobius giuris (Hamilton and Buchannan, 1822) Collected from Manchar Lake distt. Jamshoro, Sindh, Pakistan. Global Veterinaria 14: 613-618.

9. Gupta JP, Srivastava SP (2001) Maturity determination by gonadosomatic index during annual reproductive cycle in Passer domesticus. Environment and Ecology (Kalyani) 191: 216-218.

10. Soomro AN, Baloch WA, Jafri SIH, Burdi GH, Fulanda B (2012) Reproduction and feeding habits of the River Catfish Eutropiichthys vacha (Hamilton, 1822) (Siluriformes, Schilbidae) in an impacted habitat: Kotri hydrodam, River Indus, Pakistan. Our Nature 10: 269-280.

11. Rahimibashar MR, Alipour VP, Hamidi VP, Hakimi B (2012) Biometric characteristics, diet and gonad index of Lizardfish (Saurida tumbil, Bloch 1795) in North of the Persian Gulf. World Journal of Fish and Marine Sciences 4: 01-06

12. Roy A, Hossain MS, Rahman ML, Salam MA, Ali MM (2014) Fecundity and gonadosomatic index of Glossogobius giuris (Hamilton, 1822) from the Payra River, Patuakhali, Bangladesh. Journal of Fisheries 2: 141-147.

13. Kitano, Jun, Mori, Seiichi, Peichel, et al. (2007) Sexual Dimorphism in the External Morphology of the Threespine Stickleback (Gasterosteus aculeatus) Copeia 2: 336-349.

14. Soomro AN, Baloch WA Jafri SIH, Suzuki H (2007) Studies on Length-weight and length-length relationships of a catfish Eutropiichthyes vacha Hamilton (Schilbeidae: Siluriformes) from Indus River, Sindh, Pakistan. Caspian J Env Sci 5: 143-145.

15. Hossain MS (2014) Reproductive Characteristics of Bele, Glossogobius giuris from Mithamoin Haor, Kissorgonj, Bangladesh. World Journal of Fish and Marine Sciences 6: 537-543

16. Vila-Gispert A, Moreno-Amich R, Garc'ıa-Berthou E (2002) Gradients of lifehistory variation: an intercontinental comparison of fishes. Reviews in Fish Biology and Fisheries 12: 417-427.

17. Khan MSA, Alam MJ, Rehman S, Mondol S, Rahman MM (2002) Study on the fecundity and GSI of brackishwater catfish Plostus canius (Hamilton-Buchanon) J Biol Sci 2: 232-234. 